\title{
An Analysis of Age Estimation Cases in Korea from the View of Social Aspects
}

\author{
Choonik Kwon, D.D.S.,M.S.D., Jin-Seok Byun, D.D.S.,M.S.D.,Ph.D., \\ Jae-Kwang Jung, D.D.S.,M.S.D., Jae-Kap Choi, D.D.S.,M.S.D.,Ph.D. \\ Department of Oral Medicine, School of Dentistry, Kyungpook National University
}

Age estimations by forensic odontology play a great role in personal identification. The purpose of this study was to analyze the characteristics of age estimation cases in Korea. Surveying clients who requested age estimation at the Department of Oral Medicine, Kyungpook National University Dental Hospital from March 2012 to March 2013.

The results were as follows:

1. On gender distribution, females(57.14\%) were more than males(42.86\%). The elderly with $50^{\prime} \mathrm{s}$ and over $60^{\prime} \mathrm{s}$ were majorities $(89.28 \%$ ) of clients, and no clients were below 40 's. Most of clients were equal to and lower than elementary school graduate(69.64\%).

2. The most frequent reason for age discrepancy between registered age and alleged age was mistakes by family or relatives $(80.36 \%)$. The purposes of age estimation were welfare(62.50\%), social relationship problem(12.50\%), to find right age(10.71\%), and occupation( $8.93 \%)$.

3. In order of route to visit at Department of Oral Medicine, they were via government office $(48.21 \%)$, acquaintances(21.43\%), mass media(14.29\%), and clinic(10.71\%). Clients had high degree of comprehension on age estimation with forensic odontology (scored 7.03 out of 10). The $2 / 3$ of clients were satisfied with present fee for age estimation.

4. The percentage on the proximity of estimated age to alleged age was $69.81 \% .4(11.43 \%)$ clients were approved on age correction by court.

Key words: Age estimation, Social aspects, Korean age estimation clients

Corresponding author: Jae-Kap Choi

Department of Oral Medicine, School of Dentistry,

Kyungpook National University

2175 Dalgubeol-daero, Jung-gu, Daegu 700-705, Korea

Tel: 82-53-200-7311

Fax: 82-53-426-2195

E-mail: jhchoi@knu.ac.kr

Received: 2013-07-03

Accepted: 2013-07-28

* This research was supported by Kyungpook National University Research Fund, 2012

\section{INTRODUCTION}

Age estimation is important for personal identification in forensic medicine regardless of deceased or living individuals, and especially in living persons, it is necessary because of difference between the age on documents and the age a client claimed $^{1)}$. Age estimation is needed in all age groups because of the time of school entrance, employment, retirement and welfare benefits. It becomes more important with the expansion of National Pension Service and social security system ${ }^{2}$. 
Generally speaking, stature, skeleton, weight, hair and teeth are being used for age estimation. Among them, teeth are closely related with age and there have been many studies to estimate age using dental information ${ }^{3)}$. Through those studies by Lewis ${ }^{4)}$, Stewart ${ }^{5)}$, Green ${ }^{6)}$, Nanda ${ }^{7)}$, and Kurita ${ }^{8)}$ et al, teeth and jaws are developed gradually according to age and there is less individual difference or diversity, so they are very suitable to be used for age estimation. Therefore, age estimations by dentists are considered more reliable than those by doctors in society and legal circles".

To estimate age by forensic odontology, various methods such as the time of tooth eruption or $\operatorname{loss}^{10-23)}$, the level of tooth calcification ${ }^{24-28)}$, the size of pulp cavity ${ }^{29-31)}$, the degree of tooth attrition, changes in microtissue of tooth ${ }^{32,33)}$, weight of tooth, changes in mandible, and the degree of cranial sutures closure are used. Clinically, the most frequently used method in children is to judge the time of eruption and calcification of permanent teeth while in adults it is to examine the degree of tooth attrition and the changes in mandible and cranial sutures ${ }^{9)}$.

Since Hunter ${ }^{34)}$ in 1771 , there have been many studies regarding the growth and calcification of teeth by Schour ${ }^{35)}$, Nolla ${ }^{36)}$, Nortje ${ }^{37)}$ et al overseas and Chung ${ }^{13)}$ and $\mathrm{Ko}^{17)}$ et al in Korea. Chung and Ko discussed clinical and forensic research methods using teeth on Koreans. It is known that efficient and relatively accurate age estimation can be made when permanent dentition has not been established such as deciduous dentition, mixed dentition, and early permanent dentition.

Meanwhile, among changes in teeth by aging, tooth attrition is caused by normal chewing activities and the increase of attrition is thought to be natural according to aging. Of course, loss of tooth structure because of unusual mechanical process, independent of usual occlusion, like bruxism cannot be defined as attrition but abrasion. However tooth abrasion can be distinguished from attrition because abrasion causes wedge shaped notches at cervical area or limited 'step-like' wear facets on few teeth, while attrition affects on most of teeth evenly. Regarding this, there are many overseas studies by Gustafson ${ }^{3,38)}$, Martin ${ }^{39}$, Broca $^{40)}$, Miles ${ }^{41)}$, Takei ${ }^{42)}$ et al and Korean studies by $\mathrm{Kwak}^{32}, \mathrm{Ahn}^{43,44)}, \mathrm{Lee}^{45)}, \mathrm{Kim}^{46)}$ et al. Although Takei's method ${ }^{42)}$ and modified Kim's scoring system $^{47)}$ have been frequently used as reference for age estimation using tooth attrition in Korea, we need to be careful because there can be difference in degree of attrition according to gender, occupation, diet, habitual environment, and so on. Especially, given the domestic situation with high demand on age estimation for the aged, age estimation using tooth attrition can be very useful.

Finally, since Vesalius and Fallopius first reported in 1542 that the closure of cranial sutures progressed with aging ${ }^{48)}$, there have been many debates regarding the reliability of the method ${ }^{49-52)}$. In case of living individuals without teeth, age estimation by evaluating the closure of cranial sutures might be the most convenient and practical method, although age estimation can be made with range considering the tolerance of individual diversities and interexaminer errors ${ }^{11}$.

As such, age estimation by forensic odontology using maxillofacial areas including teeth is the most reliable method because dental features show less individual difference or diversification than any other organs or structures.

In Korea, demands and necessities of age estimation are very high for many different reasons. The biggest reason is that we have experienced several social upheavals in a short time which cannot be found in other countries. We have experienced the period of Japanese colonial rule, an establishment of Korean government, the Korean War and a divided country in a relatively short time. These special social events made it difficult to record birth and death registration accurately. In particular, family members or relatives have registered birth of children late because of frequent infant deaths of diseases or accidents, or because of poor transportation and communication infrastructures. There might be some administrative errors 
by public officers such as a lapse of the pen, and missing or damaged documents during the war or upheavals as well. Accordingly, some may have different age from the actual age and they may need age estimation to get an age estimation certificate for their school entrance, military service, employment, retirement, and welfare benefits such as receipt of pension ${ }^{53}$.

As such, age estimation by forensic odontology was proved to be reliable in both forensic medicine and social terms through previous foreign and domestic studies, and there have been many dental studies regarding age estimation. However, there is no report regarding social aspects of age estimation candidates. Therefore, this study tried to analyze age estimation clients as living individuals to identify social characteristics of age estimation clients in Korea. The ultimate purpose of this study is to give practical help to studies regarding age estimation methods to estimate age more accurately considering specialties of Korean society.

\section{MATERIALS AND METHODS}

\section{Subjects}

The subjects were age estimation applicants visiting at the Department of Oral Medicine in Kyungpook National University Dental Hospital from March 2012 to March 2013. Age estimation applicants in Kyungpook National University Dental Hospital for the year were 60 in total. Excluding those who could not answer the survey or did not complete the survey, 56 applicants were selected as final subjects. And then characteristics of those subjects were analyzed.

\section{Methods}

When age estimation clients came to the hospital, they were asked to answer the survey (Appendix) with informed consent. To identify the characteristics of age estimation clients, the survey asked general information including gender, age, and education level, and social characteristics such as the reason why age discrepancy was made and what they would like to get through age estimation. It also contained questions about the awareness of clients on age estimation by forensic odontology including the perception on the fee. When they finished filling out the survey, dental radiographs were taken or a dental impression was taken for dental cast models (both maxillary and mandible) according to the registered age or the age claimed by the client. In other words, when the client claimed age under 20, panoramic radiograph was taken and the calcification level of the third molars was analyzed if any ${ }^{12,37,54)}$. In case the client was over 20 , the oral examination was conducted to check and record prosthetics. After that, the dental impression was taken with alginate and dental cast models were made with stone plaster. Based on the cast models, the degree of tooth attrition was evaluated according to the classification of Takei ${ }^{42)}$ and $\mathrm{Kim}^{47)}$. In case the client was over 50, lateral and anteroposterior skull radiographs were taken to evaluate cranial sutures closure and age estimation was made according to the order of cranial sutures fusion with aging by Simpson ${ }^{54)}$. Finally, proximity between the age that the client claimed and estimated by forensic odontology was evaluated, and the decisions by court for age correction were investigated through telephone calls.

By sorting and analyzing data obtained from the survey, distributions of recent age estimation clients by gender, age, and education level, the reason why they needed age estimation and social awareness on age estimation by forensic odontology were reviewed.

\section{RESULTS}

\section{Distributions of age estimation clients by gender, age, and education level}

The distributions of age estimation clients from March, 2012 to March, 2013 in Kyungpook National University Dental Hospital by gender, age group, 
and education level are shown in Table 1,2, and 3 respectively.

There were more females in age estimation clients by gender. In age distribution, there was no applicant under 30 while over 40s, especially 50s and 60 s were absolutely major proportion of clients (89.28\%). By education level, equal to and lower than elementary school graduate showed the highest ratio (69.64\%), and there was quite high ratio of equal to and higher than college graduate (16.07\%).

Table 1. Gender distribution of clients on age estimation $(n=56)$

\begin{tabular}{ccc}
\hline Gender & No. & $\%$ \\
\hline \hline Male & 24 & 42.86 \\
Female & 32 & 57.14 \\
\hline
\end{tabular}

Table 2. Percentage of age estimation cases by age group $(n=56)$

\begin{tabular}{ccc}
\hline Age group & No. & $\%$ \\
\hline \hline$\leq 10 \mathrm{~s}$ & 0 & 0.00 \\
$20 \mathrm{~s}$ & 0 & 0.00 \\
$30 \mathrm{~s}$ & 0 & 0.00 \\
$40 \mathrm{~s}$ & 6 & 10.71 \\
$50 \mathrm{~s}$ & 25 & 44.64 \\
$\geq 60 \mathrm{~s}$ & 25 & 44.64 \\
\hline
\end{tabular}

2. Distributions according to reason and purpose of age estimation

As the reasons of discrepancy in age, the biggest portion was mistakes by family members or relatives at the time of birth registration (80.36\%), and the next reason was administrative errors such as mistakes by public officers (Table 4).

Table 4. Reasons for discrepancy between registered age and claimed age $(n=56)$

\begin{tabular}{lcc}
\hline \multicolumn{1}{c}{ Reason } & No. & $\%$ \\
\hline \hline Mistakes by family or relatives & 45 & 80.36 \\
Errors on office procedure & 9 & 16.07 \\
Others & 2 & 3.57 \\
\hline
\end{tabular}

Table 5. Percentage of purpose of age estimation $(n=56)$

\begin{tabular}{lcc}
\hline \multicolumn{1}{c}{ Purpose } & No. & $\%$ \\
\hline \hline Welfare benefits & 35 & 62.50 \\
Social relationship problems & 7 & 12.50 \\
To find right age & 6 & 10.71 \\
Occupation (employment, retirement) & 5 & 8.93 \\
Education & 0 & 0.00 \\
Others & 3 & 5.36 \\
\hline
\end{tabular}

Table 3. Percentage of age estimation cases by education level $(n=56)$

\begin{tabular}{lcc}
\hline \multicolumn{1}{c}{ Education level } & No. & $\%$ \\
\hline \hline equal to and lower than elementary school graduate & 39 & 69.64 \\
middle school graduate & 4 & 7.14 \\
high school graduate & 4 & 7.14 \\
equal to and higher than college graduate & 9 & 16.07 \\
\hline
\end{tabular}


As the reason or purpose why the clients wanted age correction through age estimation, the most frequent answer was to get social benefits provided to the aged such as pension (62.50\%), and then social inconvenience in the relationship with friends or senior-junior, to have correct age, occupation related purpose such as postponing retirement were followed (Table 5).

\section{Evaluation of awareness of clients on age estimation by forensic odontology}

The routes how they came to know age estimation using maxillofacial areas including teeth were asked (Table 6)

Half of age estimation clients came to the hospital for age estimation through government offices such as administrative office or court (48.21\%), and the next popular routes were acquaintances or mass media.

Table 6. Percentage of access routes for age estimation by forensic odontology $(n=56)$

\begin{tabular}{lcc}
\hline \multicolumn{1}{c}{ Route } & No. & $\%$ \\
\hline \hline Government offices & 27 & 48.21 \\
Acquaintances & 12 & 21.43 \\
Mass media & 8 & 14.29 \\
Clinics & 6 & 10.71 \\
Attorneys & 3 & 5.36 \\
\hline
\end{tabular}

Table 7. Degree of comprehension on age estimation by forensic odontology $(n=53)$

\begin{tabular}{ccc}
\hline Degree of comprehension & No. & $\%$ \\
\hline \hline very poor & 0 & 0.00 \\
poor & 1 & 1.89 \\
fair & 13 & 24.53 \\
good & 34 & 64.15 \\
very good & 5 & 9.43 \\
\hline
\end{tabular}

In the Likert scale survey evaluating the comprehension on age estimation by forensic odontology, most of clients showed high level of understanding (Table 7), and regarding the fee of age estimation by forensic odontology, the following opinions shown in Table 8 were collected.

\section{Evaluation on the result of age estimation}

Proximity between the age the client claimed and the estimated age by forensic odontology was evaluated (Table 9), and the results from the court were acquired from telephone calls with clients (Table 10).

Table 8. Survey on reasonable fee for age estimation $(n=51)$

\begin{tabular}{lcc}
\hline \multicolumn{1}{c}{ Fee } & No. & $\%$ \\
\hline \hline 150,000 won (present) & 34 & 66.67 \\
100,000 won & 12 & 23.53 \\
50,000 won & 3 & 5.88 \\
below 50,000 won & 2 & 3.92 \\
\hline
\end{tabular}

Table 9. Result of proximity between estimated age and claimed age $(n=56)$

\begin{tabular}{lcc}
\hline Proximity of estimated age to & No. & $\%$ \\
\hline \hline Claimed age & 32 & 57.14 \\
Registered age & 11 & 19.64 \\
Others & 13 & 23.21 \\
\hline
\end{tabular}

Table 10. Result of age correction on court $(n=34)$

\begin{tabular}{ccc}
\hline Result & No. & $\%$ \\
\hline \hline Approval & 8 & 23.53 \\
Rejection & 26 & 76.47 \\
\hline
\end{tabular}

* 19 clients did not apply for age correction, 3 clients did not answer. 


\section{DISCUSSION}

Changes in teeth and jaws according to aging are closely related with age, and it has been proved in many studies that age estimation by forensic odontology is the most appropriate method both in living and deceased individuals. In age estimation by forensic odontology, the method to evaluate the development of tooth and the level of calcification is the most frequently used for children and the method to examine the degree of permanent teeth attrition and changes in mandible and cranial sutures is the most frequently used for adults. In this study, social characteristics of the clients who visited Kyungpook National University Dental Hospital from March in 2012 to March in 2013 were analyzed to identify the trends and aspects of age estimation in the future.

According to Statistics Korea (national statistics office $)^{2)}$, the population of the aged in Korea accounts for $11.8 \%$ in 2012 and it is increasing every year. Recently, importance of welfare such as National Pension and social security system is getting bigger, and most of entitlement qualifications are based on age. Therefore, the necessity of accurate age estimation is highlighted ${ }^{533}$. In the present study, there was higher rate of females $(57.14 \%)$ than males $(42.86 \%)$ in gender distribution of age estimation clients (Table 1). This might be because people postponed birth registration of baby girl since the influence of old notion of preferring a son to a daughter and lower rate of females made social activities in past generations. By age, there was no client under $30 \mathrm{~s}$, while $50 \mathrm{~s}$ and 60 s were $44.64 \%$ respectively to account for $89.28 \%$ of total clients (Table 2). It was contrary to the result published by the Office of Court Administration ${ }^{53)}$ in $1994 ; 79 \%$ of applicants were under 30. Considering that 20 years have been passed since the publication and the current age of age estimation clients, it could be assumed that there could be many errors in registration because of administrative error owing to social upheavals that Korean society had experienced in 1940s and 1950s. It also shows that the demand on age estimation is increasing because of welfare beneficiary qualification. On the other hand, the reason why there was low rate of age estimation application among younger generations might be because fewer mistakes had been made in those times thanks to the development of transportation and communication infrastructures. When looking into the distribution of age estimation clients according to education level, it was found that equal to and lower than elementary school graduate accounted for the biggest portion such as $69.64 \%$ (Table 3). It could be guessed because less educated people had relatively lower necessity and understanding on administrative works such as birth registration. Interestingly, the second highest group was equal to and higher than college graduate. It might be because those with higher education level have relatively high understanding on age estimation procedures and high interest in social welfare benefits.

In the survey why they came to have age discrepancy between registered and claimed, most of the cases were because of mistakes by family members or relatives as $80.36 \%$ and the next was administrative errors of government offices (Table 4). As age on the registration is mostly based on the birth registration, there can be age discrepancy if family members or relatives register a birth late for various reasons. Considering social conditions, high birth rate and high infant mortality, and insufficient transportation and communication infrastructures in the past might result in late birth registration. Additionally, in case of administrative errors, age discrepancy can be made because of non-computerized documents. In the survey asking the purpose of age estimation, the biggest portion of clients answered 'to get welfare benefits such as National Pension, senior preference, and insurance benefit' (62.50\%), and other reasons such as 'relating with social relationship' (12.50\%), 'to have correct age without special reasons' (10.71\%), and 'occupation matter related to retirement and employment' (8.93\%) followed. As mentioned before, 
it should be noted that interest in and necessity for social welfare are increasing in this aging society, and the highest portion of age estimation purposes was made because of social welfare benefits. In addition, the uniqueness of Korean custom emphasizing hierarchy according to seniority is indirectly shown in age estimation clients. Regarding occupation, as most of clients were the aged, the application was more related with retirement than employment. As it can be connected to welfare as well, we can say that the major purpose of age estimation is social welfare.

According to the access route how age estimation clients came to the Department of Oral Medicine to get an age estimation certificate (Table 6), the majority came through government offices such as administrative office or court (48.21\%). The other routes were friends or acquaintances (21.43\%), mass media (14.29\%), clinics (10.71\%), and attorneys (5.36\%). Considering that it is the legal procedure to make a final age correction through age estimation, the ratio excluding government offices and attorneys (46.43\%) shows that the awareness on age estimation by forensic odontology is quite high in our society. In the 5-point Likert scale survey on the understanding of clients on age estimation by forensic odontology, it showed high degree of comprehension such as 7.03 out of 10 , confirming the high understanding of general public on age estimation by forensic odontology (Table 7). Meanwhile, in the evaluation of clients on the fee of age estimation by forensic odontology, the majority (66.67\%) showed satisfaction with present fee (about 150,000 won in Kyungpook National University Dental Hospital as of 2012) (Table 8).

When the proximity between the estimated age by examining the degree of tooth attrition and changes in cranial sutures closure and the age claimed by the client was evaluated, similar age to the claimed age had come in $57.14 \%$, similar to the registered age in $19.64 \%$, and in $23.21 \%$ it was hard to fall under either one. Although it has been well-known that age estimation using teeth and jaws is the most reliable method and in particular age estimation using the third molars is highly accurate ${ }^{12,21,32,37,54)}$, we had to evaluate the degree of permanent teeth attrition and changes in cranial sutures closure due to the clients' age distribution. Although tooth wear can be varied according to gender, occupation, diet and cranial sutures closure also has individual difference and there can be interexaminer variation, these methods are based on statistical method, so they will not have problems in effectiveness. After age estimation, following-up whether approval or rejection on age correction by court through telephone calls to clients, was found that $23.53 \%$ of cases were approved, and $76.47 \%$ of cases were rejected among 34 decisions, while 19 clients did not file because of personal reasons, and 3 clients did not answer. It was not consistent with $76.3 \%$ approval on age correction reported in 1994. It might be because court become more rigorous on age correction. Actually, court requires other supporting documents such as birth certificate, education certificate, and employment certificate other than age estimation certificate by dentists ${ }^{53}$. When the rejection cases and non-filing cases were investigated, most of those cases reported that they had not had supporting documents other than age estimation certificate. In addition, there are many age correction cases with minor discrepancy such as 1 or 2 years, so that decisions by court are made from considering other documents practically as well as age estimation certificate even if age estimation by forensic odontology is known to be reliable.

To summarize the above study results, from the analysis of Koreans who have recently applied for age estimation, it was found that there was great demand in the aged over 50. It seems that this special demand is resulted from the uniqueness of Korean society in 1940s and 1950s such as the period of Japanese colonial rule, an establishment of Korean government, the Korean War, and division into the North and the South Korea after the War. Additionally, as entering an aging society, interest in social welfare and the demand on age estimation are increasing to receive welfare benefits. It was a 
good opportunity to confirm the importance of forensic odontology as a part of forensic medicine by reviewing social perception of age estimation by forensic odontology. Finally, through the aforementioned case analysis, we could collect basic data on the trends and the characteristics of age estimation from the view of social aspects unlike previous age estimation studies, and those data are expected to suggest directions to future studies on age estimation.

\section{CONCLUSION}

As there have not been recent reports on age estimation clients, we asked age estimation clients visiting at the Department of Oral Medicine in Kyungpook National University Dental Hospital from March 2012 to March 2013 to answer the survey. We could collect 56 responses. The analysis results of the collected data are as follows:

1. In the distribution of age estimation clients by gender, there were more females $(57.14 \%)$ than males $(42.86 \%)$, while the aged such as 50 s and 60 s were $89.28 \%$ by age group. According to education level, the biggest portion was those who were equal to and lower than elementary school graduate.

2. The biggest reason of age discrepancy between registered age and claimed age was mistakes by family members or relatives $(80.36 \%)$, and the purposes of age estimation were shown as welfare benefits $(62.50 \%)$, social relationship problems $(12.50 \%)$, correction of age without special reasons $(10.71 \%)$, and occupation related matters $(8.93 \%)$.

3. In routes how they came to know age estimation in dentistry, through government offices was the highest answer (48.21\%), and the ratios through acquaintances, mass media or clinics were high as well. The comprehension on age estimation by forensic odontology was high such as 7.03 out of 10. Regarding age estimation fee, more than half of the clients showed satisfaction with the present fee.
4. The result of age estimation by forensic odontology showed $57.14 \%$ proximity to the claimed age. Among the age estimation clients for a year of study period, $23.53 \%$ of clients made age correction legally.

\section{REFERENCES}

1. 김종열. 법치의학. 서울. 2005 . 지성출판사. $182-3,308-$ 309 .

2. 통계청. 2012 고령자통계. 2012. 한국개발연구원.

3. Gustafson G. Forensic odontology. London. 1966. Staples Press.

4. Lewis AB, Garn SM. The relationship between tooth formation and other maturational factors. Angle Orthod 1960;30(2):70-77.

5. Stewart TD. New developments in evaluating evidence from the skeleton. J Dent Res 1963;42(1)Pt 2:264-273

6. Green LJ. The interrelationships among height, weight and chronological; dental and skeletal age. Angle Orthod 1961;31(3):189-193.

7. Nanda RS, Chawla TN. Growth and development of dentitions in Indian children. I. Development of permanent teeth. Am J Orthod 1966;52(11):837-853.

8. Kurita LM, Menezes AV, Casanova MS et al. Dental maturity as an indicator of chronological age: radiographic assessment of dental age in a Brazilian population. J Appl Oral Sci 2007;15(2):99-104.

9. 김영구, 신금백, 고명연 등. 법치의학. 7판. 서울. 2007. 신흥인터내셔날. 162-164.

10. Carlos JP, Gittelsohn AM. Longitudinal studies of the natural history of caries. I. Eruption patterns of the permanent teeth. J Dent Res 1965;44:509-516.

11. Cha MH. Study of normal eruption time of Korean permanent teeth. KMJ 1963;8(10):97-107.

12. Choi JH, Kim CY. A study of correlation between the development of the third molar and second molar as and aid in age determination. Korean J Oral Med 1991;16(1):121-136

13. Chung SC. A study on the eruption time of permanent teeth with the eruption phases in Korean-I: Studies on the eruption phases of permanent first molars. Korean J Oral Med 1977;3(1):11-22.

14. Gustafson G, Koch G. Age estimation up to 16 years of age based on dental development. Odontol Revy 1974;25(3):297-306.

15. Hur YD, Ahn JM, Yoon CL. A Study on the age determination with the aid of mandibular molar 
development. Korean J Oral Med 1994;19:221-230.

16. Kim JC, Han KS. A study on the classification of the stage of root development and crown eruption for permanent teeth. Korean J Oral Med 1999;24(1): 95-106.

17. Ko MY, Chung SC. A roentgenographic study on the development of roots of mandibular permanent posterior teeth. Korean J Oral Med 1981;6(1):23-34.

18. Lysell L, Magnusson B, Thilander B. Eruption of the deciduous teeth as regards time and order. Int Dent J 1964;14:872-879.

19. Moorrees CF, Fanning EA, Hunt EE Jr. Age variation of formation stages for ten permanent teeth. J Dent Res 1963;42:1490-502.

20. Mörnstad H, Staaf V, Welander U. Age estimation with the aid of tooth development: a new method based on objective measurements. Scand J Dent Res 1994;102(3):137-143.

21. Myeong DS. Roentgenographic studies on the development of mandibular permanant third molar in Korean. New Med J 1968;11:985-989.

22. Rah HC, Kim CY. Study on the eruption age of the first molar. Korean J Oral Med 1994;19(1):57-72.

23. Savara BS, Steen JC. Timing and sequence of eruption of permanent teeth in a longitudinal sample of children from Oregon. J Am Dent Assoc 1978;97(2):209-214.

24. Daito M, Kawahara S, Tanaka M et al. Calcification of the permanent first molars observed in panoramic radiographs. J Osaka Dent Univ 1989;23(1):45-55.

25. Hess AF, Lewis JM, Roman B. A radiographic study of calcification of the teeth from birth to adolescence. Dent Cosmos 1932;74:1053-1061.

26. Kraus BS. Calcification of human deciduous teeth. J Am Dent Assoc 1959;59:1128-1136.

27. Liliequst B, Lundberg M. Skeletal and tooth development : a methodological investigation. Acta Radio 1971;11:97-112.

28. Staaf V, Mörnstad H, Welander U. Age estimation based on tooth development: a test of reliability and validity. Scand J Dent Res 1991;99(4):281-286.

29. Chung ET, Kim CY. An estimation of age bases on the changes in the human dental cavity caused by increase in age (By surface index of pulp cavity). Korean J Oral Med 1981;6(1):101-110.

30. Hong HC, Ko MY. A study on the change of pulp cavity of the adult posterior teeth by ageing. Korean J Oral Med 1993;18(1):107-108.

31. Kim DK, Kim CY. An estimation of age based on changes in the pulp cavity caused by and increase in age. Korean Dent Assoc 1981;19(5):439-448.

32. Kullman L, Martinsson T, Zimmerman M et al. Computerized measurements of the lower third molar related to chronologic age in young adults. Acta Odontol Scand 1995;53(4):211-216.

33. Kwak KW, Kim CY. Comparative study of age estimation accuracy in Gustafsons's method and prediction formula by multiple regression. Korean J Oral Med 1985;10(1):73-89.

34. Hunter J, Bell T. Treatise on the natural history and diseases of the human teeth. Philadelphia. 1839. Haswell, Barrington, and Haswell. 40-53.

35. Schour I, Massler M. Studies in tooth development: The growth pattern of human teeth. J Am Dent Assoc 1940;27:1918-1931.

36. Nolla CM. The development of the permanent teeth. J Dent Child 1960;27:254-266.

37. Nortje CJ. The permanent mandibular third molar. Its value in age determination. J Forensic Odontostomatol 1983;1:27-31.

38. Gustafson G. Age determinations on teeth. J Am Dent Assoc 1950;41:45-54.

39. Martin R, Saller K. Lehrbuch der anthropologie in systematischer Darstellung. Stuttgart. 1957. Gustav Fischer Verlag.

40. Broca P. Instructions rélatives a l'étude anthropologique du systéme dentaire. Bull Soc Anthrop Paris 1897;2(3):128-163.

41. Miles AEW. Dentition in the assessment of individual age in skeletal material. New York. 1963. Pergamon Press. 191-209.

42. 竹井哲司. The use of tooth attritions in age estimation, part 2. 日法醫誌 1981;35(6):400-410.

43. Ahn HJ, Park JS. A study on the attrition of the posterior teeth in the aged adult by aging. Korean J Oral Med 1995;20(2):399-406.

44. Ahn HJ, Park JS. Ko MY, A study on the age estimation by attrition of the adult teeth. Korean J Oral Med 1998;23(1):85-99.

45. Lee MC. Study on the degree of teeth of teeth attrition with age increase of the Korean. Korean Dent Assoc 1972;10(7):445-450.

46. Kim YK, Kho HS, Lee KH. Age estimation by occlusal tooth wear. J Forensic Sci 2000;45(2): 303-309

47. Yun JI, Lee JY, Chung JW et al. Age estimation of Korean adults by occlusal tooth wear. J Forensic Sci 2007;52(3):678-683. 
48. Ashley-Montagu MF. Aging of the skull. Am J Phys Anthropol 1938;23:355-375.

49. Lovejoy CO, Meindl RS, Mensforth RP et al. Multifactorial determination of skeletal age at death: a method and blind tests of its accuracy. Am J Phys Anthropol 1985;68(1):1-14.

50. McKern TW, Stewart TD. Skeletal age changes in young American males: analysed from the standpoint of age identification. United States Army. 1957. Natick, Mass. : Headquarters, Quartermaster Research \& Development Command.

51. Singer R, Estimation of age from cranial suture closure: report of its unreliability. Journal of Forensic Medicine 1953;1:52-59
52. Stewart TD. Essentials of forensic anthropology, especially as developed in the United States. Springfield, 1979. Charles C Thomas Pub Ltd.

53. 법원행정처. 개명 및 호적정정 사례집. 1994:24-33, 240-257.

54. Lee JJ, Kim CY. A study on development of the third molar as an aid in age determination. Korean J Oral Med 1985;10(1):53-62.

55. Simpson K. Taylor's principles and practice of medical jurisprudence. London. 1965. I. \& A. Churchill Ltd. 


\section{APPENDIX}

연령 감정에 관한 설문 조사

설문에 참여해주셔서 감사합니다.

본 설문지는 귀하의 의견을 통해 연령 감정에 대한 연구를 위한 참고 자료로 사용될 목적으로 작성되었으며, 연구 목적 이외에 다른 용도로 사용되지 않습니다. 안심하시고 있는 그대로의 의견을 기입해 주시면 감사하겠습 니다.

$<$ 개인 정보>

1. 성별

(1) 남성 ( ) (2) 여성 ( )

2. 연령 (세)
(1) $<10 \quad(\quad)$
(2) $10 \sim 19 \quad(\quad)$
(3) $20 \sim 29$
(4) $30 \sim 39 \quad(\quad)$
(5) $40 \sim 49 \quad(\quad)$
(6) $50 \sim 59$ ( )
(7) $\geq 60$

3. 최종 학력

(1) 초졸 이하 ( ) (2) 중졸 ( )

(3) 고졸 ( ) (4) 대졸 이상 ( )

<연령 감정의 사회적 배경>

4. 호적상 나이와 실제 나이가 차이가 나게 된 이유는 무엇입니까?

(1) 가족 혹은 친척의 실수

(2) 행정상의 오류

(3) 기타 (

5. 연령 감정을 통해 얻고자 하는 혜택은 무엇입니까?

(1) 복지 (국민 연금, 경로 우대 등)

(2) 직업 (취업, 정년 연장 등)

(3) 학업 (입학, 졸업 등)

(4) 기타 (

<법치의학적 연령 감정에 대한 인지도>

6. 치과(구강내과)에서 연령 감정을 한다는 사실을 어떠한 경로를 통해 알게 되었습니까?

(1) 관공서 (동사무소, 법원 등)

(2) 주변 사람

(3) 대중 매체 (방송, 인터넷 등)

(4) 병의원

(5) 기타 (

7. 법치의학적 연령 감정 방법에 대해 잘 이해하셨습니까?
(1) 전혀 그렇지 않다
(2) 그렇지 않다
(3) 보통이다 ( )
(4) 그렇다
(5) 매우 그렇다

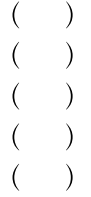

8. 현재의 연령 감정 비용(약 15 만원)이 적절하다고 생각하십니까?

(1) 그렇다 ( )

(2) 그렇지 않다 ( ) (본인이 생각하는 비용을 적어주십시오; 
국문초록

\title{
사회적 측면에서 본 한국 연령 감정 대상자 사례의 분석
}

\author{
경북대학교 치의학전문대학원 구강내과학교실 \\ 권춘익 · 변진석 · 정재광 · 최재갑
}

법치의학적 연령 감정은 개인 식별에 있어 중요한 역할을 한다. 본 연구는 한국 연령 감정 대상자들의 사회적 특성을 분석 하는 것을 목적으로 한다. 2012년 3월부터 2013년 3월까지 경북대학교 치과병원 구강내과에 연령 감정을 의뢰한 대상자들에 게 설문조사를 실시하였다.

결과는 다음과 같다:

1. 성별 분포에서, 남성(42.86\%)보다 여성(57.14\%)이 더 많았다. 50대와 60대 이상의 고령자가 대다수였으며(89.28\%), 40대 아래로는 한 명의 의뢰인도 없었다. 의뢰인들의 대부분이 초등학교 졸업 이하의 학력을 가지고 있었다(69.64\%).

2. 호적 상 연령과 의뢰인이 주장하는 연령 간의 차이가 나게 된 가장 큰 이유로는 가족 및 친척의 실수로 인한 것이 가장 많았다(80.36\%). 연령 감정을 통해 얻고자 하는 목적은 사회 복지 혜택(62.50\%), 사회적 인관 관계 문제(12.50\%), 단지 바 른 나이를 찾기 위해서(10.71\%), 직업과 관련한 문제(8.93\%) 순이었다.

3. 연령 감정을 하기 위해 치과(구강내과)를 찾게 된 경로로는 관공서의 비중이 높았으며(48.21\%), 친구나 지인(21.43\%), 대중 매체(14.29\%), 병의원(10.71\%) 등을 통한 경로가 뒤를 이었다. 법치의학적 연령 감정에 대한 의뢰인들의 이해도는 10 점 만점에 7.03점으로 높은 수준이었다. 절반 이상의 의뢰인들에게서 현재의 연령 감정 비용에 대해 만족하는 것으로 나타났 다.

4. 법치의학적 연령 감정을 통해 감정된 연령과 의뢰인들이 주장하는 연령 간에는 $57.14 \%$ 의 근접도를 보였다. 1 년 간 조사한 연령 감정 대상자들의 $23.53 \%$ 가 법적으로 연령 정정을 하게 되었다.

주제어: 연령 감정, 사회적 측면, 한국 연령 감정 대상자 